\title{
Investigating Piracy and Terrorism in the International Legal System
}

\author{
Dr Bagher Shamloo ${ }^{1} \&$ Seyed Ahmad Sajadi ${ }^{2}$ \\ ${ }^{1}$ Professor of Shahid Beheshti University of Tehran, Iran \\ ${ }^{2} \mathrm{PhD}$ student of International law, Shahid Beheshti University of Tehran, Iran \\ Correspondence: Seyed Ahmad Sajadi, PhD student of International law, Shahid Beheshti University of Tehran, \\ Iran. E-mail: sajadi1390@gmail.com
}

Received: May 24, 2017

doi:10.5539/jpl.v10n4p125
Accepted: June 10, 2017 Online Published: August 30, 2017

URL: https://doi.org/10.5539/jpl.v10n4p125

\begin{abstract}
Laws governing piracy has been evolving during historical periods. Pirates as human enemies have been undisputed theme of common international laws and most of the international treaties. The reason why piracy could be the most continuous historical phenomena in more than two thousand years is that it is in link with the other factor which is, in turn, in continuity during the history and it is nothing but violence. During the centuries, piracy has faced tolerance and even in some cases circumstantial satisfaction of political societies and in the next step the governments. Even in some cases it was used to set the relations of power. At the time of the rule of Elizabeth I in England piracy faced a lot of tolerance because this crime was the means of making a living for English pirates. It seems that one of the reasons making England facilitate free sailing in its bodies of water by seventeenth century was making the opportunity for pirates by English sailors for getting by. In this study we are going to discuss marine crimes in international laws.
\end{abstract}

Keywords: marine crimes, international laws, piracy, political

\section{Introduction}

\subsection{Part 1: Different Dimensions of Piracy from the Perspective of International Laws}

Clause: historical record of piracy

Piracy is one of the exceptions of the free principle of sailing and it is a crime that can be traced back to the ancient era, more than three thousand years ago. It is mentioned in Hammurabi tablet, in the part specialized for the penalty of illegal seizure along with the use of violence by the swimmers. Piracy was first defined in the Iliad and the Odyssey by Homer and it was a popular profession in the Greek mythology. The evidence in the carved clay tablets reveals that the oldest pirates lived in the Egyptian pharaohs' era and it was related to the pirates' attack on cargo ships in the Mediterranean Sea and the north of Africa continent. Before Christ, piracy was counted as a legal and legitimate action in the Mediterranean Sea. This trend continued until pirates ruined the path of commerce to the east and Africa, at this time some treaties were signed among the governments to suppress pirates. The Roman Empire welcomed the battles against pirates and in 67 B.C eventually a Roman commander called the Great Pompeii was ordered to clear the Mediterranean Sea of pirates. While little by little and based on the concepts of ancient Rome, piracy was considered as an international crime and universally qualified, the attitude toward pirates changed in time and it reached its so-called golden era at the time of Elizabeth and $16^{\text {th }}$ and $17^{\text {th }}$ century (Bagheri Mahmoudabadi, 2010).

In this regard, most of the marine attacks were done through armed commercial ships based on the guidelines received against the ships that were considered as enemies. Thus, piracy turned into the cause of terror and violence under the support of government. In the same way, English, French and Netherland's ships arranged their attacks toward the ships whose governments hadn't paid their annual tax. In such situations the sentences between an official or tactical military action at the part of a government and the actions of piracy varied. in this era, pirates didn't act lawlessly, but a set of regulations called "articles related to pirates" were considered as the behavioral rules for arranging the ships of pirates as an independent unit. Along with the end of the seventeenth century, at the same time as the end of wars among the powerful marine governments, the government opposed them and the marine governments' regulations started struggling against pirates. Hence, in eighteenth and nineteenth centuries, we witnessed referring to the laws of ancient Rome and the negative attitude toward the issue of piracy; such that the laws of governments more and more considered piracy as a crime against humanity. 
In $19^{\text {th }}$ and $20^{\text {th }}$ centuries due to many factors, we saw a reduction in pirates' attack, but despite international society's attempts to struggle against this phenomenon, in the middle of 1990, piracy was mentioned as an important and critical marine challenge; especially strait of Mallaca in South Asia that witnessed an increase in pirate's attack in 1990 and early 2000.

During the last centuries, Southeast Asian governments, especially Indonesia, Malaysia and Singapore made an effective attempt to struggle against piracy in their coasts. Such attempts led to the extermination of piracy in this area to a high extent. However, piracy still exists in some parts of the world such as Southern China Sea, Bengal Gulf, Aden Gulf, territorial waters of Somalia, Nigeria coasts, Oman Sea, Guinea Gulf, Caribbean Sea, Malacca Strait, Singapore and the waters linking Pacific ocean and India, especially in the recent years the actions of Somalian pirates in Aden Gulf and the coasts of this country menaced naval security and international commerce and resulted in drawing the society's attention to put an end to the issue of piracy and armed banditry against ships in the Horn of Africa and Indian ocean (Ghorbanpour,2009).

\subsection{Second Clause- The Definition of Piracy from the Perspective of International Law}

Investigating different dimensions of piracy from the perspective of international law and the related elements requires a historical attitude on its definition, elements and various dimensions. On this basis, in this clause we are going to discuss the historical perspective of piracy, the definition of piracy from the perspective of the treaties of marines' laws and different elements of this crime.

\subsection{Third Clause: Different Elements of Piracy}

\subsubsection{Legal Element}

With regard to the legal element of the crime of piracy, the emphasis of this article is on the Geneva Convention in 1958 and the law of marines in 1982.

the agreement of struggling against illegal actions against the security of navy (enacted in 1988), the agreement of struggling against hostage taking (enacted in 1979), the agreement of United nations in struggling against transnational organized crimes (enacted in 2003) and the agreement of struggling against corruption (enacted in 2003) are new legal international tools for struggling against international crimes.

\subsubsection{Material Element}

What clearly manifests diversity in the definition of piracy is paying attention to actions included in this crime as its material elements. The agreements of the laws of marines mentioned some cases under the material title constituting the crime of piracy that are going to be mentioned in the following parts. With regard to the first material element, while according to the committee of lawyers, (being deprived of property and violent actions against people) was considered as the constituent of the material element of piracy, along with determining a documented legal framework for defining common international laws of piracy, the legal conventions of marines mentioned the following as piracy: any kind of illegal violent action, arresting, looting and loss of property of each ship, plane or against people as well as the property of ships and planes out of the competence of the other ships. The second constituent of the crime of piracy, according to the definition of international conventions of marines laws is the limitation of geographical areas of applying the cases, including piracy (executive global competence) related to them to (free seas and international waters). In other words, the actions performed in the realm of ground water of each state are not considered as piracy, even if such actions are in the form of illegal seizure of the target ship (victim) by the invading ships and they are simply for personal goals such as asking for money or hostage taking. This regulation has two important results: firstly, such attacks against underground waters (even in exclusive economic zone) or seaports are not counted as piracy (Heydari, 2011).

In other words, such attacks taking place in the range of the territorial jurisdiction of countries generally include Armed Robbery against ships, an expression that despite International Maritimic Organization (IMO) and the other institutions includes hijacking as well. The limitations of this regulation, especially in terms of all or some parts of violent actions against ships in Somalian coasts and the territorial sea of this country make such instances exceptions from the definition of piracy. The second result of this regulation is that restricting piracy to free seas and international waters, the executive global competence being awarded to all the countries in international waters does not apply to chasing the pirate ship in the waters of a territory under the jurisdiction of coastal state. As it is stipulated in the articles of convention in terms of chasing, it must be stopped as soon as the target enters its country or another country. Thus, the marine ability to stop chasing by entering the waters of a territory such as Somalian coasts remains a problem. With regard to the third element, according to the conventions of the laws of marines, piracy must be composed up swimmers; the victim and the invader. In other words, if the pirates get on the target ship in the coast and the swimmers start piracy in the free sea during the 
journey, such an action is not legally qualified as piracy due to the absence of invading swimmer. Thus, this characteristic doesn't include different kinds of violence without necessarily clash of the two ships such as the violent seizure of a ship by the crew or the passengers even due to looting the ship. On the same basis, the attempt of passengers to control Santa Maria Portuguese ship in 1961 and Achille Lauro Italian passenger ship in 1985 by a group of Palestinian hostage takers who had entered the ship as a passenger with political incentives, are not counted as piracy (Hashemi, 2001).

According to the authors of the International Laws of the Seas, the necessity for the presence of two pirate ships and the victim ship to realize the title of piracy distinguishes such a state from hijacking. In addition, according to the interpretation of the commission of international laws in the interpretation of the convention of 1982 of the laws of the seas, the actions done on the ship by the crew and the passengers are not counted as piracy. it should be noted that despite the view of commission in compiling the convention of 1958 of Geneva, it was stipulated in the final plan of the convention of 1982 that violent actions by any invading ship or plane against people and property in the victim ship or plane in the free seas and the places out of the jurisdiction of states are counted as piracy. The considerable point based on the conventions of the laws of seas: ((contribution and leadership in committing piracy equals to the stewardship in committing the crime)).

\subsubsection{Spiritual Element}

Convention of United Nations in terms of laws of seas enacted in 1982 as the constitution of the oceans in the world, considers piracy as an illegal action committed based on personal goals. The recent feature distinguishes piracy from marine terrorism that is correlated to political objectives -in terms of the spiritual element in committing piracy, there is consensus in personalization of the goals of pirates in appealing to the actions counted as the crime of piracy in almost all of the treaties and procedures related to compiling international laws on struggling against piracy- is carried out against a ship in a free sea. In other words, the actions done beyond the free waters by a plane against another one are hardly ever counted as the crime of piracy.

In addition, if piracy is committed by warships or state ones and the plane whose staff are in rebellion taking control of the ship or plane, it will be so that they are committed in a private ship. Otherwise, the nature (formality) of the measures of the aforementioned ship and the fact that the measures are not taken for personal purposes, prevents the inclusion of piracy on such cases. In this regard, inclusion of the title of piracy on the tragedy of the Achille Lauro was doubted because the pirates had an especial connection with the state or an identity similar to the state (Mohammadi,2010).

\subsection{Clause Three- Nature and the Aim of Committing Piracy}

In this part, first with the analysis of the components of international crimes written in the association of international criminal court and armed banditry against ships in the sea, its conformity or non-conformity with the current criminal acts in the Somalian coasts and Aden Gulf, we are going to describe the nature of committing such a crime, then we will scrutinize the traditional and new aims of committing this crime.

\subsection{The Nature of Piracy}

The most important question posed in the field of the nature of piracy is that if it should be among the international crimes mentioned in the association of penal international court or it can be argued that piracy is an independent international crime having specific components. On the other hand, what are the similarities and differences between piracy and armed banditry in the sea? To clarify the discussion, first we describe the components of the aforementioned international crimes and then we will investigate its conformity or non-conformity with the current criminal acts in Somalian coasts and Aden Gulf.

\subsubsection{The Crime of Genocide and Piracy}

Genocide is referred to as the actions to destroy all or some part of a national, ethnic, racial or religious group in the association of international penal court that meets the definition of article 2 of the convention of genocide in 1948; such actions are written clearly in the article 6 of the association.

This group of crimes, being considered as the clearest instances of crime against humanity, are committed by authorities and non-governmental people at the time of peace and an international or non-international armed hostility. However, basic condition of this crime is the same intention written in article 6, which means intending to destroy. It, in fact, forms spiritual element of crime and in case of lack of such a condition this action may be counted as the crimes against humanity or war crimes. On this basis, the piracy committed in Somalian coast cannot be counted as crime because it lacks the spiritual element of (the intention of destroying) and the material element (destroying all or part of an ethnic, national, etc. group and humanity). 


\subsubsection{Crime against Humanity and Piracy}

Crime against humanity is each of the actions specified in clause 1 of article 7 of the association of Rome being committed in the form of a big and organized attack against non-civilians. The attack includes a behavior against every non-civilian population following the policy of a government or an organization of a state. Thus, the three factors of attack against non-civilians, vastness and organization of attack, being aware of the attack are essential for the realization of crimes against humanity. Crimes against humanity have been recognized since the time of the agreement of Versailles, but it was flourished in the association of Nuremburg court. However, some of its articles are seen in the associations of international penal courts for the former Yugoslavia and Ruanda. In addition, crime against humanity has been taken into account in the special court for Sierra Leone (Rezapour).

\subsubsection{War Crime and Piracy}

The international responsibility of war crimes was first mentioned in the Versailles treaty (1919). Contrary to the other crimes, war crimes are recognized in international laws and there are lots of national and international approaches with regard to them. The association of court adopted a different approach in this regard in article 8 . Generally, some of the war crimes mentioned in article 8 have traditional origin and some others are based on conventional principles. The association mentioned war crimes in the form of international or non-international armed hostility. In the association it was attempted to consider those crimes as the war ones that are undoubtedly traditional and based on common law. Writing committed crimes in the form of four conventions of Geneva didn't follow any discussion and the outstanding cases of violating the laws of armed clashes were put under the jurisdiction of the court in the form of the four conventions of Geneva. This precondition that the crimes are committed widely is the main difference between the association and the proceedings of the four conventions. According to the current approach, piracy and its accompanying crimes in Somalian coasts are not committed under war conditions and didn't violate traditional provisions, despite the inclusion of some of the instances of war crimes to the committed crimes in the Somalian coasts presently, it doesn't include stipulated components for the realization of war crimes (Ebrahim Nazari, 2009).

\subsubsection{Crime against Peace and Piracy}

One of the instances of crimes against peace was the invading war in which the Public Assembly ratified the provisions of invasion in 1927 for the first time the court is qualified to attend such crimes. At the conference in Rome no specific definition was agreed for invasion.

Therefore, such crimes are out of the jurisdiction of the court, unless its provisions are approved with regard to the terms of correcting the association. Reviewing the components of crime against peace, we will get to know that criminal actions committed in Somalian coasts and Aden Gulf that endangered international peace and security can be counted as a crime against peace in one perspective.

\subsubsection{Piracy and Armed Banditry against Ships in the Seas}

In the resolution of the Security Council the two terms piracy and armed banditry against ships in the waters of Somalia and free seas near Somalian coasts are used together to extend the range of regulations of international laws. The above-mentioned expression is usually used in the international structure of sailing and can include violent actions, the intention of which is the same as piracy, but it is not covered by the conventional definition of piracy. Particularly, because it may be committed without using the invading ship against the target one. In the resolution of A922 (22) enacted in November $29^{\text {th }}$, International Maritime Organization ratified 2001 guidelines of research in terms of piracy and armed banditry against ships whereby armed banditry against ships means every illegal violent action, seizure or every act of looting or threatening to that in the range of waters of the state (even civil rivers and lakes), while piracy is an action taking place against a ship or its people or property (in free seas) and in the competence of a government on such crimes; this definition is repeated in article 1 (2) of the agreement of regional cooperation in struggling against piracy and armed banditry against ships in Asia enacted in April $28^{\text {th }}, 2005$ and in article 1 (2) of the guideline of the support of the International Maritime Organization related to suppress piracy and armed banditry against ships in the eastern Indian ocean and Aden Gulf enacted in January $29^{\text {th }}, 2009$ in Djibouti. The stipulation of (armed banditry) in the resolution of the Security Council was due to include all actions related to piracy such as the possible ones in the future (Sayyari, 2010).

\subsubsection{Piracy as an Independent International Crime}

Based on the analysis of the components determined for international crimes, it seems that piracy as an independent international crime meets special components in the background and the traditional laws of states, piracy was one of the earliest international crimes and it has always been counted as a lawbreaker and the enemy of humanity. Due to committing this crime, the pirate and its swimmer, in turn, are deprived of the support of 
their government and the state having the flag. In the view of Cicro, pirates must be considered as the enemy of human beings because this crime must be counted out of the jurisdiction of an especial state, despite the pirates must be prosecuted according to the civil laws after being arrested, there is the right of prosecution for all the states. This competence basis is reflective of an independent crime that includes global jurisdiction as the first international crime (Bledsoe, 1996).

\subsection{Piracy with the Permit of the State}

Their method is also like the regular piracy, except that they loot the commercial ships of the enemy under the surveillance of the state, as a payment or referring to the permissibility of seizing the commercial ships of the enemy and looting them by (letter of marque) issued at the part of the government or the monarchy.

For example, in 1787 the US allowed the assembly of this country to issue the permit of seizing and looting the commercial ships of the enemy and retaliatory actions. This permit (letter of marque) has been recognized by the international conventions and it means such robbers cannot be accused of piracy as long as they attack for their intentions in their mission. This legal discretion doesn't always save the relevant people and that person is considered as a pirate or an executor of the mission of legal piracy, it highly depends on the fact that the victims are attacked under the protection of the country where issued the permit or under the protection of the target. Spanish authorities executed such foreign pirates while putting the permit of looting commercial ships around their necks so that they could emphasize the rejection of such an action in their view. In addition, some of them exceeded the limits of the issued permit and attacked the navy of the commercial ships of the countries that were in peace (Thomas To and William Kid were such pirates) and as a result, they put themselves in the convention of struggling against piracy. However, such permits provided a cover for their pirates, such that the looted property from the disinterested ships or companions will be paid back after looting commercial ships of the enemy (Bledsoe, 1996).

The most popular pirate ships were Berbery in Mediterranean, Maltese Coursers to the command of S.T John under the Ottoman Empire and Dancickers were at the Spanish Empire's service. Only from 1626 to 1634 the state pirates looted 1499 ships and drowned 336 ships. From 1609 to 1616, England lost 466 commercial ships as a result of such robberies and 160 British ships were captured by Algerians between 1677 and 1680. One of the most popular pirate was Sir Francis Derik. His advocate was Queen Elizabeth I. It has been proven that their relationship had lots of benefits for England. State pirates constituted a high percentage of the military forces in the sea in $17^{\text {th }}$ and $18^{\text {th }}$ centuries. During the 9 year war, the French adopted a policy to reinforce state piracy that the attacks of Jean Bart to the Dutch and English ships were its effect. England lost almost 4000 commercial ships during the war. Following the wars for gaining office and succession in Spain, the attacks of pirates continued and Britain lost 3250 commercial ships. During the wars over the succession in Austria, Britain lost 3238 commercial ships and France lost 3434 ones on the way to Britain. During the war of the George king (some of the wars took place in the north of America for substituting Austria) almost 36000 Americans provided service as state pirates before or after that. At the time of the American Revolution, there were 55 thousand American sailors working on the ships as state pirates. They had around 1700 ships and captured 2283 ships of the enemy. Between the end of the war of revolution and 1812, less than 30 years, Britain, France Nipple (Napoli, a harbor in the southwest of Italy) and Berbery countries (9Islamic countries of the north of Africa), Spain and Netherland captured almost 2500 American ships. The tax and compensations paid to Berbery countries included about 20 percent of the annual income of the US in 1800. During the civil wars of America, the state pirates' union managed to disturb unity of commercial navy. Privateering was removed with the ratification of international law in Paris in 1856 (Convention on the Law of the Sea, 1982).

\subsubsection{The Place of Committing Piracy}

In the past, pirates wandered about free sea and attacked commercial ships. That's why all the regulations regarding piracy and struggling against that have been discussed in free sea. But, today the nature of their work has changed, such that they work in civil waters near the coast instead of wandering about the ocean. The new piracy can be seen in the areas such as the coasts of the Caribbean Sea, Ecuador, Africa, Nigeria, Somalia, Bengal Gulf, and Southeast Asia. Anyhow, when we talk about the novelty of this type of piracy we should be careful because it has been common in Southeast Asian states for centuries. The result of this change in the nature is that the current regulations regarding piracy have lost their effect, in other words, they were passed to meet the issues of that time and they can't meet the present requirements. As a result, the regulations of the convention of the laws of seas regarding piracy must be reviewed (Speech of the Dr. Abbas Tavazonizadeh, 2010). 
We should be realistic in facing with the issue of piracy, most of the states consider the convention of the laws of seas successful. It is obvious that this convention has been based on a mutual consent and attempted to meet the needs of participating states in the conference. This convention has solved some of marine problems, but it has made other problems. However, the problems are not so serious that they can cause a review, in terms of this problem we can pass a protocol. But the protocol is only applicable for the signatories and in case the states (with the occurrence of piracy on their sea) are not present, the protocol won't be in effect anymore. The other point to be taken into account is that as it was mentioned before, the free sea has become narrow with the expansion of the width of the sea from 3 to 12 miles. Thus, such a vase sea allows the pirates to go on with their activity in a relief in case the coastal state is not able to control the area under his sovereignty and such areas will turn into a safe paradise for them (Ibid).

\subsubsection{Time Conditions of Committing Piracy}

Collecting provisions most of the time leads to clarification in that area. The articles of the convention of free sea were written in the articles 100 to 107 of the convention of the laws of the seas without any modification. Thus, we can assume two issues with regard to piracy in the twentieth century:

1) Piracy has a long origin that has been removed to a high extent and in the case of the current cases, the marine navy of the big powers that go around the seas can fight with such limited cases.

2) The right of sovereignty of the states always precedes the measures related to preventing piracy and struggling against that. The logical result is that all the measures taken regarding piracy during the last century lack the index of urgency and necessity to struggle against piracy regardless of the fact that which institute takes the responsibility (the committee of the League of Nations, Harvard group, the commission of International Laws or the convention of the Laws of the Seas). However, the current statistics reveal that piracy is growing day by day and draws the world attention. Whereas, by appealing to the conventional and traditional laws discussing piracy in only free sea, we have no choice but resorting to regional measures to cope with this crime. In the second chapter, such measures and barriers regarding them, are doing to be discussed (Speech of the Dr. Abraham Beygzadeh, 2010).

\subsection{Chapter Two: Terrorism}

An increase in the terrorist acts during the recent years, especially after the terrorist attack of September $11^{\text {th }}$ to the twin towers, has turned terrorism into one of the considerable problems in the world. Although today the word terrorism is seen in many books, journals and newspapers around the world, different states offered a different definition for that and it is not an easy task to come to a consensus. It should be pointed out that the word terrorism is not born out of the terrorist attack of September $11^{\text {th }}$, but it has its root in the history and means terror. In the recent decades, this term has found a legal meaning, so providing a legal definition in this regard is necessary. Not providing a single definition from terrorism causes disagreements in the meaning and the nature of this phenomenon and even in some cases the question to be posed is that: is the action marine terrorism or piracy?

\subsection{Clause One: The Meaning of Terrorism}

Although authors and lawyers keep using this term, they don't provide an individual definition. The problem with terrorism is that the lawyers define it based on the recent events, that they call them terrorist events. However, to achieve an exact legal definition, we need to define the phenomenon with regard to the meaning that comes out of its essence. Because the definitions provide based on the recent events doesn't include previous events on the one hand and probably they won't cover future events as well on the other.

\subsubsection{The Meaning of Terrorism in the Doctrine of Lawyers}

In the Merriam Webster dictionary the following definition is given for this entry: (violation or destructive actions (such as bombing) taking place by a group to intimidate a population or a state to attain their goals).

As it is seen this definition didn't specify the terrorists' goals. It means it is not clear if the performed actions are for personal, political or religious purposes. Terrorism can be counted different from the other crimes, it is by far more dangerous than the other aggressive actions in the seas.

In a terroristic event we should at least consider seven factors that include:

1. Wrongful act, 2. Intention, 3. Characteristics of the victims, 4. Criminals' relationship with government, 5. The incentive for committing, 6. The level of organization, 7. Not being guilty. Anyway, we cannot find a definition for terrorism by resorting to all such elements because all of the cases cannot be in one terroristic act and there will be a counterexample in the face of every provided definition. If it is stated that terrorism must be 
committed with an especial intention, we can mention the terrorist attack of September $11^{\text {th }}$, the aim of which is not still clear. If it is said that the terrorist acts must directly committed against non-civilians, then how attacking the USS Cole military ship will be warranted? If unintentional or political destruction of property counts as a terroristic act regardless of its reason, what can be stated regarding Boston Tea Party Incident?

This incident happened in December $16^{\text {th }}, 1773$, means the time when Boston in the Massachusetts, current US, was the colony of Britain. Such that after the authorities of Boston refused to return the three ships containing tea (this consignment was as a tax to be delivered to Britain), some of the inhabitants of Boston attacked the ship and threw the consignment to the sea. This was a direct protest to the law of tea in 1773 that should be ratified by British assembly.

In terms of defining terrorism, we must consider all relevant elements, but we shouldn't expect them to take place in a specific incident. Some people like Antonio Cassese believe that despite people's imagination, international laws in fact defined international terrorism and started legislating about that. He considers terrorism as the action including the following elements. 1 . It is an action that is usually criminalized in civil laws, 2 . It has supranational nature which means it is not only committed.

Against an especial state and it has transborder effects. For example, the preparations of a terroristic attack may take place in another country. It is an action carried out to make a government or an international organization to do or quit an action, 4. For attaining the foregoing case there are two models: first, spreading fear and terror among the people, second, attacking private and state institutes or their representatives, 5. Generally, the aim of such actions is not private but it takes place due to attaining ideological or religious (Moslemi, 2005).

\subsection{Second Clause: The Relationship between Terrorism and Piracy}

The practical approach similar to terrorists and pirates, most of the time causes mixing. Thus, we face some problems in determining the nature of emerging offences. In this regard, we are attempting to case study such actions and see what kind of connection is there in the two concepts. The reports of spying organization in the West reveal that some extremist Islamic groups declared that they are trying to ruin the economy of these countries to reach their religious goals. The statement can be concluded so that the groups are attempting to use piracy as a method to affect the economy of West. If the aim of attacking Nagot is counted as a compensation to the economy, we come to a conclusion that piracy can be indirect aim of terrorists.

Although terrorist groups accept the responsibility of their actions, they can commit an action like drowning a ship in such areas as Hormuz strait, Malacca Strait, Bab al Mandeb strait and Suez Canal use the common methods of pirates. Anyway, there is no evidence showing that the terrorists intentionally use piracy as a war method. Certainly, attacking NAGOT, USS Cole and MV Limburg are not counted as piracy but they are counted as terrorist attacks with economic and military aims. the outstanding example in this regard was seizing an Achille Loro ship by the Palestine Liberation Front (PLF) in 1985, following the event, a considerable economic record took place in entertainment shipping industry and the economy of the countries where deal with this kind of shipping. This event didn't happen anymore, but the reason for this repetition was luck, but an increase in security measures. In other words, still there is a chance for such measures and no dissuasive security measure has been taken. The liberation movement of Palestine has never sought an economic record in West, but as it was stated some of the terroristic groups tend to harm the fragile economy of west this way. Now, after twenty years of the occurrence of this event, a terrorist attack doesn't only disturb entertaining ship industry, but it can disturb the economy of all the world. As a result, it can be stated that the Achille Lauro incident was a terrorist attack followed by political goals and is never counted as piracy. In this regard, there is a theory, on the basis of which terrorist groups can reach their goals through committing piracy and consequently they can take advantage of the same methods as a piracy for committing their actions. But it was also mentioned in the previous lines that terrorist attacks follow especial goals, while piracy is usually accidental and uncoordinated. However, in this case we cannot be completely sure because as it was mentioned, the statistics show that the new pirates don't go around the free sea to find their baits and they have pre-determined plan for their attacks.

It seems unlikely for a terrorist group to have a confederate outside the group, from among the pirates! Because the terrorist groups are interrelated and impervious and they suspect the aliens that are not in their group, especially if they don't have a shared ideology with them. But it is possible that terrorist groups commit piracy without partnership with the other criminal groups. In the subsequent lines the activities of some terrorist groups and the goal of their plans are going to be described (Heydari, 2011). 


\subsubsection{Abu Sayyaf Terrorist Group}

The Abu Sayyaf group that is seeking to create an Islamic state in the south of Philippines is recognized with the events such as abduction and piracy.

International records reveal that there are shades of differences between piracy and terrorism and this group has been turned from an Islamic and Separatist group into a criminal organization. If this theory is accepted, it should be stated that the group shifted its political goals into the private ones in committing its criminal acts. But this group hasn't retreated from its terroristic positions. Such that it took the responsibility of attacking Supper ferry 14 in 2004, in fact, it can be stated that this group keeps on with its terroristic activities, but it also commits piracy and looting to provide its financial resources (Sayyari, 2010).

\subsubsection{The Free Aceh Movement Terrorist Group}

The Free Aceh Movement is another terrorist group dealing with piracy. This group is seeking to overthrow the Indonesian government and its headquarter is in Aceh, Sumatra. Indonesian and Malaysian authorities believe that this group commits piracy due to attain financial benefits. The most important area of its activity is Malacca strait and possibly most of the events took place in this area is attributed to this group. However, as it denies the events, their activities cannot be accurately evaluated.

In addition, it has been reported that pirates feigned this group as a uniform technique so that a large number of attacks are attributed to Aceh group (Ibid).

\subsubsection{Al Etihad Al Islamite Group}

The local organization of this group is in one of the areas in which piracy is common, it means Horn of Africa, and it is assumed that they also commit piracy. This group is made of people whose loyalty and resorting to foreign confederates caused a large spectrum of terroristic and criminal acts in the area. This group is also seeking to create an Islamic government in the Horn of Africa and it seems that it commits piracy to provide its financial resources. However, most of the events are reported to be done by armed gangsters whose actions are based on tribal loyalty other than the tie with Al Etihad Al Islamite group. These gangsters are armed, in other words, they are pirates but terrorists. In the recent months, piracy has been increased in this area. So that even the ships carrying humanistic helps of the United Nations were have been attacked and its passengers and crew have been taken as hostage for weeks and months (Ibid).

\subsubsection{Al Qaida Group}

There have been speculations regarding the plot of an Al Qaida group for committing piracy and terrorism.

After the terroristic event of September $11^{\text {th }}$, the analysis related to maritime, the reports of state agencies and the reports of newspapers suggested that this group has a maritime navy which is ready to attack ships and ports all over the world. When the tensions resulting from the attack of September $11^{\text {th }}$ were rested, it was specified that none of the suspected ships were committing terroristic activities and only a few of them were related to the other illegal actions such as abduction and item trafficking. This group was seemingly involved in USS Cl and MV Limburg attacks, but they were never involved in piracy (Ibid).

\subsubsection{Liberation Tigers of Tamil Eelam}

Tamil Tigers is the name of another group being active in the seas and has an armed maritime force called Tigers of the Sea that commit piracy against foreign commercial ships. It has recently been reported that this group doesn't need to commit illegal acts such as piracy to provide its incomes, but they tend to commit maritime terrorism.

Attacks took place in some areas such as Southeast Asia are usually counted as terroristic events rather than piracy. In March 2003, Dewi Madrim engine ship was impounded by pirates, but many people believed that such pirates are, in fact, terrorists because the reports suggested that they didn't want to plunder ships, but they impounded the ship to gain experience in maneuvering with ship and took some of the crew as hostage due to learning skills of maneuvering with the ship. Despite the experts of maritime security count such events as a terrorist attack, there isn't enough evidence to prove such a claim (Ibid).

\subsection{Chapter Two: The Other Crimes}

As it was mentioned, conventional laws helped common law through signing treaties and attempted to criminalize committed crimes. In the previous chapter terrorism was investigated. The other crimes criminalized by conventional laws include drug and human trafficking through the sea. Irrespective of the menaces resulting 
from such crimes, it should be acknowledged that these two crimes are not broadly considered by states like terrorism, but lots of regional, trans-regional and domestic measures have been taken to struggle against that.

Since in this article it has been attempted to discuss limiting factors of freedom principle in the free seas, these two crimes are going to be dealt with briefly.

\subsection{Clause One: Drug Trafficking}

Drug trafficking is one of the most important menaces against the security of the sea. About 70 percent of seized drugs are captured while shipping. Trafficing such drugs is a criminal act that can be followed by many issues such as: illegal activities of the crew of commercial ships and concealing drugs in the containers for carrying commercial consignments. Fishing, entertaining and container ships are especially considered by the relevant unions. Drugs are often concealed in legal consignments in the load containers without the cooperation of the crew.

Fishing ships are also used as the means of transporting, refueling from the coast and its storage. Drug cartels often change the route to avoid inspection and responding to the drug markets.

\subsubsection{The Convention of Laws of the Seas 1982}

Convention of the laws of the seas asks the countries that own flag to control the ships that hoisted their flag effectively. In terms of enforcing the laws of a coastal country, the regulations of harmless passage, transit passage, Archipelago passage, adjacent area and instant right of chasing are specifically related, but in the free seas and exclusive economic zone the convention of the rights of seas asks all the states struggle against drug trafficking through ship and requires other countries to repress trafficking in case the country owning the flag fails to provide logical reasons why its ship is doing such activities (Taghizadeh, 2012).

\subsubsection{Trafficking through Sea}

(The convention of 1988 of the United Nations against drug trafficking and psychedelic drugs) asks the members to exert their competence on such crimes in its ships. Article 17 of this convention completes the enforcement of article 108 of the convention regarding the laws of the seas and for contracting states except for the state owning the flag makes it possible to inspect and stop a ship in case it has logical reasons showing that the ship is transporting illegal items.

\subsubsection{Regional Measures}

In the regional year, two agreements have also been signed to facilitate the convention of 1988 regarding drugs. 1) The agreement of 1995 of European Council regarding trafficking through the sea in line with enforcing article 17 of the convention of drugs regarding drugs against the illegal transportation of drugs and psychedelics. 2) The agreement related to the cooperation along with struggling against airway and waterway trafficking of drugs and psychedelics in the Caribbean. Both agreements make it possible for the other contracting countries, except for the state owning the flag, to inspect suspected ship when it is around the sea of a state. According to the Caribbean agreement, the primary satisfaction of the state owning the flag is not required unless the state clearly antagonizes that. Except for the participating countries that discuss practical problems regarding the implementation of the convention of drugs, for example, encourages the necessity for recording the ship in article 17 of the United Nations regarding drugs and the crimes of collaboration through mediating and exchanging information with respect to illegal sailing, in the framework of the plan of controlling containers (Tahmasebi).

The United Nations Administration has also created a channel for exchanging information in terms of the crimes of drugs enabling states to receive and submit warnings about displacing suspected containers, besides, it has created a project on law enforcement and cooperation in terms of information against smuggling of cocaine from Latin America to western Africa through enhancing the ability to struggle. The International Maritime Organization also provided modified strategies to prevent drug trafficking with regard to the ships doing international transportation. In Latin America and the Caribbean, national measures have been taken in this regard as well. At the same time, in the Europe the importance of the role of analyzing maritime operations with an emphasis on drugs affirms an important point for exchanging information and operational coordination. In Africa, there is close cooperation of executive officials with European officials (Ziaee Bigdeli, 2005).

\subsection{Clause Two: Immigrants' Trafficking through the Sea}

Every year lots of people enter different countries without the permission of officials by escaping from the borders and become victims of human smuggling and illegal immigration. Illegal immigration has various reasons. Including: escaping from war, violations to human rights, economic shortcomings, the poverty of the 
government and lack of natural resources. Illegal immigration usually requires considerable risks such as: the risks resulting from non-maritime ships, non-human conditions in the ship, being abandoned in the sea by the smugglers. With the increase of illegal immigration as well as exploitation of immigrations, the international community needs to take an urgent action in all the levels of struggling against human trafficking and recognize illegal immigration. The destinations are especially worried about the effective protection of borders, controlling immigration and struggling against international organized crimes. The enforceable legal framework for international immigration through sea has different forms and includes international human rights, the rights of refugees and the enforceable laws on transnational organized crimes (Speech of the Dr. Jamshid Momtaz, 2010).

\subsubsection{Convention of the Laws of Marines 1982}

This convention didn't investigate the issue of trafficking of human and immigrants directly, but generally it asks the owner of flag to have an effective control on the ships that hoisted its flag. In terms of implementing the laws of other countries, the regulations regarding the harmless passage, transit passage, archipelago passage of adjacent zone, the right for instant chasing and the right of inspection are specifically related to human smuggling. The documents related to human smuggling, including protocol against the smuggling of migrants by land, sea and air, and the protocol to prevent, suppress and punish trafficking in persons, especially women and children adjunct to the United Nation Convention against transnational organized crimes enacted in 2000. The first document which is regarding human smuggling in the sea is going to be our next subject.

\subsubsection{Palermo Protocol against Smuggling of Migrants through Land, Sea and Air}

This document has been signed to suppress and struggle against smuggling of migrants and enhancing cooperation of members in this regard as well as supporting the rights of immigrants.

\subsection{Public Regulations}

Migrant smuggling means an action to gain financial benefit directly or indirectly through entering people who are not the permanent resident of that state implemented to a member. Illegal entering means passing the borders without having the required documents for the legal entrance to the accepting country. Forged documents or forged identification papers are documents that fake or altered ones and include any document issued by every person other than the one at the part of government or at the part of person other than the one who has the legal right to use the document. According to this protocol, migrants shouldn't be prosecuted because the subject of aforementioned crimes has been in article 6 . According to this article, every member takes action for creating a crime when it is committed with the intention of gaining direct or indirect financial benefit.

* Migrant smuggling

* creating fake documents of traveling or making the process of creating such documents

* making a person who is not the permanent resident of a country stay in that country through using illegal individual means or the above-mentioned individual ways; While that person doesn't have the required documents to stay in that country legally (Speech of the Ing. Mohammad Souri, 2010).

\subsubsection{Migrant Smuggling through Sea}

This part of protocol asks members to cooperate in preventing or suppressing migrant smuggling through sea, according to the international laws of the seas. Then, it considered two presumptions for performing such actions that include the doubt of statelessness of the ship and the statelessness. In the first case if a member has logical reasons showing that a ship hoisted its flag or has the claim of record in that country, it is without nationality or it hoisted the flag of a foreign country or avoids showing its flag, it is suspected that migrants smuggling is through sea, it can ask the other members to struggle against such ships and the demanded state must take due measures. In addition, in case a member has logical reasons showing that a ship is sailing and hoisted a flag or shows the mark of its record in another country, is smuggling it can notify the state owning the flag. The state owns the flag must immediately take due measures after notification to see if the ship is really registered under its flag or not and it may give the following authorities to the notifying country:

* Inspection of the ship

* searching the ship

* If it has the evidence showing the ship is smuggling human, it can take actions considering the ship, people and its consignment in the range that the country owning the flag permitted.

After getting permission and inspecting, the inspecting state must immediately report the result of its inspection to the state owning the flag. It cannot take any action that is not permitted by the country owning the flag. Except 
for the measures that are necessary for repelling an imminent risk or the actions resulting from mutual or multilateral agreements. In the second case, if the ship is stateless and the inspecting state has logical reasons for this statelessness, it can inspect the ship and in case its doubt turns into certainty through this inspection, it can take proper measures based on the civil and international laws. Therefore, it can be stated that this protocol gives permission to enter the ship, inspect or do everything regarding the ship that is suspected to smuggling migrants with the permission of the state owning the flag and with the guarantee of protecting them. None of the issues mentioned in the protocol influences the other laws and requirement of states and people, being created based on international laws. Such as: humanistic international laws, international human rights and especially the convention of 1951 and its protocol of 1967 related to the state of refugees, wherever enforceable. In addition to the other requirements, the protocol of human smuggling asks the states to take measures to prohibit commercial vehicles to be used for smuggling and support the victims of such crimes. Before ratification of the protocol of the migrants, in 1988 the International Maritime Organization took binding measures to struggle against dangerous actions related to smuggling migrants through the sea. Such measures are related to some of dangerous action related to the operations of sailing, (for example, violating the international convention for having a secure life in the sea) that endangers the life and health of people in the ship. The International Maritime Organization also publishes the report of risky actions related to migrant smuggling through sea twice a year. The issues related to those who get on the ship illegally, which means without a ticket, include cooperation in preventing illegal getting on, the captain's requirements to provide the welfare of illegal passengers and allocation of responsibilities after finding the illegal passenger, being discussed in the Convention on Facilitation of International Maritime Traffic (Study the problem of pirates).

\subsubsection{Regional Measures}

The problem of illegal immigration by sea, which has been a reinforcement of the cooperation between governments. Inclusive of African and European governments have focused on the following topics.

1) Control and monitoring the boundaries of the target countries to prevention of illegal trips by sea.

2) Strengthening the capacity of countries of origin, to identify the people who need to be supported by international instruments.

3) Management of migration through legal channels.

4) The origins of migration.

The first ministerial meeting European - Mediterranean on immigration has Algarve Spain in 18 and 19 November 2007 taken place and to conclude that the obligations with regard to illegal immigration leads, legal immigration, immigration and Development. In this context, one of the challenges was the Immigration complex, in the sense that people can rely on international law to enjoying the rights and protection of many, and governments should ensure that these individuals are fully supported.

\subsection{The Actions of the Security Council and the International Community}

\subsubsection{Security Council Measures}

In the center of countermeasures, the Security Council has the primary responsibility for the maintenance of international peace and security resolutions on the situation in Somalia issued numerous, including 1814, 1816, $1838,1844,1846$ resolutions. In fact, in 2008 the highest resolutions of the Council were devoted to this issue, which shows the importance of it. Council under Chapter VII of the Charter and in accordance with the request of the President of Somalia, the international community adopted Resolution 1851 to combat piracy. This resolution approval of all 15 council member states name it allows for piracy crack in the sea to be armed and to take all necessary measures. Also in the resolution of all the countries that can participate actively requested pirate ship or aircraft and combat the region. It is worth mentioning that the measures contained in the resolution on Somalia. Then all countries and international organizations are encouraged to coordinate their activities in the fight against piracy as soon as possible a "mechanism for international cooperation" introduction. In fact, unless unprecedented outbreak of Somali piracy unprecedented international cooperation in the field seas had worried. A coalition led by France, America, Britain and India in patrolling the Gulf of Aden, the course allowed, China, Korea and Iran also play an active role (Robin Churchill \& Alain Lu, 2009).

\subsubsection{The Actions of the International Communities}

In 2008, a group of countries, managed environment in the Gulf of Aden International Security Patrol. Pirate prepared big worry for India, because it is an important part of India's trading with the ship through the Gulf of Aden and finally, India was forced to send naval ships to this logic. Russia joined the international fight against 
pirates, but it was outside of the international framework and it had happened in an independent basis. France is the only country that transmits on the basis of UNCLOS, the pirates after the arrest in its territory. The only country that has sunk the pirate ship is India. British troops and American have to supply usually pirates to Kenya preferably after his arrests. In Kenya, these thieves are sentenced typically up to seven years in prison. In some cases, some Marine units due to certain national laws in their country after the arrest and disarm bandits, they have released them. In September 2008 Danish warships, had released ten of these pirates after six days arresting. What is certain, the national laws of the involved countries and some human rights considerations, in pursuit of the thieves are cumbersome. In addition, what according to many, such encounters are cross sections solutions with Somali pirates and radical to end this issue will not be considered. On 23rd September 2008 the Russian warships arrived in the waters of the country to fight Somali pirates. On September 29th, US warships occurred in the region. NATO on 24 October, to protect the vessels carrying food aid under the UN World Food Programs wear, three ships from the UK, Italy and Greece were sent to the region. Their mission was ended on 12 December. After the end of the NATO mission, European Union and other international organizations on December 8 sent six warships to the waters near Somalia, in this field of action. Its mission is to protect ships carrying food from the World Food Programs vessels and other merchant ships and fight pirates were announced. The Islamic Republic of Iran has announced other countries on December 20 that their warships has been sent to the area to patrol the waters of the Gulf of Aden and to protect Iranian ships. Then announced South Korea, sent its warships to cooperate with other countries in the region, the troops of the country in the first days of the New Year were sent to the coast of Somalia. Japan had also announced its readiness to send its troops in Somalian water. This military presence had effectiveness disorders in preventing or at least pirate operations, but these activities are largely repulsive than to hunt and arrest the pirates. This alone is not enough to stop the thieves who are driving the large material incentives. In addition to the high cost of the troops in the region to send also added that it is less likely, perhaps against paying ransoms for hostages. Although measures to control suspicious vessels and in some cases also led to the arrest of the robbers. Even with the recent resolution of the Security Council about Piracy law by setting to enter the territory of Somalia has opened to fighting them. But the "trial" of the thieves is still one of the unsolved problems that we try to consider it (Ibid).

\section{Prosecution and Trial and Punishment}

But for the punishment of pirates, there is still no comprehensive and efficient mechanism faced. Countries that arrest pirates, usually due to the high costs they renounce to transfer the pirates to their land and have entrusted this task to neighboring countries. For example, England has an agreement with Kenya to transfer the arrested pirates to the court in Kenya. The rebels in Kenya are sentenced maximum to 7 years. The Netherlands has requested in this respect for international tribunal. The dominant approach to coalition forces after the arrest and release of pirates have been disarmed it. Also noted is the transfer of pirates to third countries, namely Kenya, contrary to Article 105 of the 1982 Convention, which says: Prosecutors should be done by the courts of the country where the arrest occurs. Piracy under international law such as international Water Treaty in 1958 and the contract law of the sea in 1982, is a global crime. But the arrest and trial of pirates is not an easy task. Europe Union, the United Kingdom, and the United States of America have signed an agreement whereby the Kenyan courts are able to prosecute suspected pirates, and two groups of pirates who were arrested by patrol England for trial have been sent to Kenya. Participating jurisdictions other in the process countries. Piracy suspects awaiting trial in France. Five Somalis in piracy in the Netherlands suspected in May on charges of trying a cargo ship attempted to hijack in January in the Gulf of Aden. Some countries are reluctant to prosecute pirates in its territory, because of the fear that the pirates may claim "an unfortunate and tragic situation in Somalia" to seek asylum. Some other countries may also be due to concerns related to human rights or fair trials in sending suspects to some specific countries to act with caution. Those who are responsible for prosecution and trial of the suspects, faced with the problem of access to credible witnesses, especially when key witnesses of the crew and personnel on merchant ships are traveling. Strategies to arrest and charge the pirates are increasingly being used, in particular the International Convention on the fight against the taking of hostages and the UN Resolution 1851, which would allow it to stop piracy off the Coast of Somalia - with the permission of the government - and chased the pirates on land use all necessary facilities (Bledsoe, 1996). However, in examining the phenomenon of piracy from the perspective of justice is raised two important issues:

1) The criminalization

2) Requiring states to arrest, prosecute and convict the pirates first matter of the shortcomings of the 1982 Convention, talk show is a crime, although the Convention on criminalization and punishment of pirates suffered because of on the one hand the 1982 Convention does not require member states to criminalize acts of piracy and other international instruments that similar actions should criminalize piracy crime was helpful, such as the 1988 
Convention (unlawful seizure of ships), which requires Member States to criminalize the (IR Iran members) and the Convention in December 1979 (on the prohibition of hostage-taking) that the Security Council has not referred to Iran as a member According to the United Nations Convention on the law of the sea pirates after his arrest and trial were transferred to their territory. India is the only country that has attempted to sink the pirate ship. British forces and America usually have preferred pirates to Kenya after his arrest deliver what is certain domestic laws of the countries involved and some human rights considerations, in the prosecution of the thieves are cumbersome.

\section{Conclusion}

Two critical masses in this article were specifically examined, including piracy and terrorism. On piracy and terrorism. Piracy in some regions of the world today has become an international problem. In this regard, great efforts have been made. But as mentioned above, where a government, urging it to protect its sovereignty, even with the phenomenon of piracy, and permission to deal with it pays not grant any government interference. On the contrary, in cases where the existence of a formal government is weak, with all sorts of interventions of humanitarian intervention to military interventions by Security Council resolutions as well. For example, we have always been in Southeast Asia witnessed the activities of pirates. The area for coastal states and governments of the region is very important. But as mentioned, the new Governments in the region typically have, the percentage of those who effectively maintain its sovereignty. For example, Malaysia and Indonesia have consistently affirmed that the region was able to secure a vital highway (Malacca Strait). They accept the support of Continuous power under conditions and that their efforts for security and to create anti-crime initiatives in the region. On the contrary, it is sufficient that the situation in Somalia embodiment of our multinational state, this state-of-1990 is not able to exercise effective governance. Pirates also benefited from this situation are to commit piracy in Somali waters. The Somali government has therefore repeatedly asked the United Nations to combat this problem. As a result of the numerous resolutions of the Security Council demands. All that have been approved under Chapter VII of the United Nations Charter and on the territory of Somalia issued to combat pirates. As a result of piracy, we find that governments continue to insist on the need to protect its sovereignty and they try to associate the gaps through regional cooperation, bilateral agreements and fulfill.

\section{References}

Bagheri Mahmoudabadi, A. (2010). Marine modern stealing: new challenges to the international community the importance of international justice.

Bledsoe, R. (1996). culture of the international law, translated by Bahman Aghaei, Ganje Danesh Publications, First Edition.

Churchill, R., \& Lu, A. (2009). Law of the Sea, translated by Bahman Aghaei, publications Ganje Danesh, Fifth Edition.

Convention on the Law of the Sea, 1982.

Ghaedi, H. A. (2011). pirates from yesterday to today, the Mana information network.

Ghorbanpour, M. (2009). The performance Analysis of the international community in response to acts of piracy off Somalia and in the Gulf of Aden. International Journal of Legal Affairs of the Presidency, 26(41), 217.

Hashemi, K. (2001). measures the international community in the fight against international crime and sea. MA thesis in International Law, Tehran University, p. 13-14.

Mohammadi, M. (2010). piracy in Somali waters from the perspective of international law. Retrieved from www.mohammadziaei.blogfa.com

Moslehi, M. (2005). Persian-English Law Dictionary. Ghalam.

Rezapour, M. (n.d.). cultural and artistic institutions and consumer information website Nour Rasekhoun.

Sayyari, H. (2010). Everything about piracy.

Speech of the Dr. Abbas Tavazonizadeh (Beheshti University professor) at the conference of international law and piracy, on Saturday, 10/12/1388 at the Hall of Justice Beheshti University, 31.02.2010.

Speech of the Dr. Abraham Beygzadeh (Beheshti University professor) at the conference of international law and piracy, on Saturday, 10/12/1388 at the Hall of Justice Beheshti University, 31.02.2010.

Speech of the Dr. Jamshid Momtaz (Beheshti University professor) at the conference of international law and piracy, on Saturday, 10/12/1388 at the Hall of Justice Beheshti University, 31.02.2010. 
Speech of the Ing. Mohammad Souri (Beheshti University professor) at the conference of international law and piracy, on Saturday, 10/12/1388 at the Hall of Justice Beheshti University, 31.02.2010.

Study the problem of pirates, the Islamic Republic of Iran Army News, www.aja.ir.

Taghizadeh, Z. (2012). anti-piracy developments from the perspective of international law (1 ${ }^{\text {st }}$ ed.). knowledge Ganje Danesh Publishing, Tehran.

Tahmasebi, R. Pirates legendary in the real world, Tabnak information site, www.tabnak.ir.

Ziaee Bigdeli, M. R. (2005). Public International Law (22nd ed.). Ganje Danesh Publication.

\section{Copyrights}

Copyright for this article is retained by the author(s), with first publication rights granted to the journal.

This is an open-access article distributed under the terms and conditions of the Creative Commons Attribution license (http://creativecommons.org/licenses/by/4.0/). 